ex vivo lung perfusion perfusate during the recovery of severely injured lungs may also prove to result in positive outcomes.

Despite the promising findings of their study, further examination of this therapeutic drug needs to be performed in different animal models (preferably a large animal transplant model) to evaluate its preclinical potential within a more translational setting. Furthermore, although the dosing of NSA was arbitrarily set based on previously published literature, the optimal dose and timing of administration are the next step toward optimizing this therapeutic strategy.

\section{References}

1. Chambers DC, Cherikh WS, Goldfarb SB, Hayes D, Kucheryavaya AY, Toll AE, et al. The International Thoracic Organ Transplant Registry of the International Society for Heart and Lung Transplantation: thirty-fifth adult lung and heart-lung transplant report-2018; focus theme: multiorgan transplantation. J Hear Lung Transplant. 2018;37:1155-68.

2. Thabut G, Mal H. Outcomes after lung transplantation. J Thorac Dis. 2017;9: 2684-91.

3. Yusen RD, Edwards LB, Dipchand AI, Goldfarb SB, Kucheryavaya AY, Levvey BJ, et al. The Registry of the International Society for Heart and Lung Transplantation: thirty-third adult lung and heart-lung transplant report-2016; focus theme: primary diagnostic indications for transplant. J Hear Lung Transplant. 2016;35:1170-84.

4. Bharat A, Narayanan K, Street T, Fields RC, Steward N, Aloush A, et al. Early posttransplant inflammation promotes the development of alloimmunity and chronic human lung allograft rejection. Transplantation. 2007;83:150-8.

5. de Perrot M, Liu M, Waddell TK, Keshavjee S. Ischemia-reperfusion-induced lung injury. Am J Respir Crit Care Med. 2003;167:490-511.

6. Ueda S, Chen-Yoshikawa TF, Tanaka S, Yamada Y, Nakajima D, Ohsumi A, et al. Protective effect of necrosulfonamide on rat pulmonary ischemiareperfusion injury via inhibition of necroptosis. J Thorac Cardiovasc Surg. 2022; $163:$ : 113-22.

7. Dhuriya YK, Sharma D. Necroptosis: a regulated inflammatory mode of cell death. J Neuroinflammation. 2018;15:199.

\title{
Commentary: A journey of a thousand miles begins with a single step
}

\section{Anna Elisabeth Frick, MD, and Konrad Hoetzenecker, MD, PhD}

Ischemia-reperfusion injury (IRI) remains the leading cause of primary graft dysfunction in lung transplantation and is considered the most important risk factor in early morbidity and mortality. ${ }^{1}$ One of the prevailing features of IRI is necroptosis, a recently recognized category of cell death. Traditionally, cell death has been divided into controlled, programmed cell death (apoptosis), and accidental cell death (necrosis). Necroptosis displays features of both: the initiation of necroptosis is tightly regulated, and necroptotic cells trigger a strong inflammatory response.

From the Department of Thoracic Surgery, Medical University of Vienna, Vienna, Austria.

Disclosures: The authors reported no conflicts of interest.

The Journal policy requires editors and reviewers to disclose conflicts of interest and to decline handling or reviewing manuscripts for which they may have a conflict of interest. The editors and reviewers of this article have no conflicts of interest.

Received for publication Jan 26, 2021; revisions received Jan 26, 2021; accepted for publication Jan 26, 2021; available ahead of print Feb 6, 2021.

Address for reprints: Konrad Hoetzenecker, MD, PhD, Department of Thoracic Surgery, Medical University of Vienna, Waehringer Guertel 18-20, 1090 Vienna, Austria (E-mail: konrad.hoetzenecker@meduniwien.ac.at).

J Thorac Cardiovasc Surg 2022;163:e124-5

$0022-5223 / \$ 36.00$

Copyright (c) 2021 by The American Association for Thoracic Surgery

https://doi.org/10.1016/j.jtcvs.2021.01.116
Necroptosis has been described as a relevant factor in a variety of diseases. ${ }^{2,3}$

In this issue of the Journal, Ueda and colleagues ${ }^{4}$ report on the efficacy of necrosulfonamide, a mixed-lineage kinase domain-like protein inhibitor, in a rat pulmonary ischemia-reperfusion injury model. The number of 
necroptotic cells in the lungs was significantly decreased in the necrosulfonamide study group. This resulted in less inflammation, improved oxygenation, and better lung compliance.

We would like to congratulate Ueda and colleagues on this well-conducted study and the excellent results. The authors come from a well-known lung transplant center, which is highly acknowledged for its work in basic research.

"A journey of a thousand miles begins with a single step" is a famous quote from the Chinese philosopher Lao-Tze. Ueda and colleagues have successfully made this first step, but many more must follow before necrosulfonamide can be implemented in the clinical routine. The results of this study are intriguing; however, there is one major limitation: the rat hilar clamp model, which served as the basis of all experiments. A hilar clamp model only partly resembles the complex changes a donor organ undergoes during lung transplantation (eg, damage related to donor brain death, prolonged cold ischemic time, immunologic aspects). Therefore, it is imperative to confirm the effect of necrosulfonamide in a rat/mouse transplantation model. Then a large animal model, such as a porcine single lung transplantation model, has to follow. This step is critical, because a considerable number of promising agents targeting IRI have failed the transfer from small to large animal models.

Anticipating the far end of this "road of a thousand miles", necrosulfonamide could be tested in human donor lungs not suitable for lung transplantation. This approach is increasingly used to assess new therapeutics and their effect on human tissue without the risk of harming a patient. ${ }^{5,6}$ Only when this last milestone has been passed successfully, necrosulfonamide can be introduced in the clinical routine.

Thus, the road ahead is terribly long-but then again, without this important first step made by Dr Ueda and colleagues, the goal of treating IRI will always remain elusive.

\section{References}

1. Snell GI, Yusen RD, Weill D, Strueber M, Garrity E, Reed A, et al. Report of the ISHLT Working Group on primary lung graft dysfunction, part I: definition and grading - a 2016 Consensus Group statement of the International Society for Heart and Lung Transplantation. J Heart Lung Transplant. 2017;36:1097-103.

2. Vandenabeele P, Galluzzi L, Vanden Berghe T, Kroemer G. Molecular mechanisms of necroptosis: an ordered cellular explosion. Nat Rev Mol Cell Biol. 2010;11:700-14.

3. Sprooten J, De Wijngaert P, Vanmeerbeerk I, Martin S, Vangheluwe P Schlenner S, et al. Necroptosis in immuno-oncology and cancer immunotherapy. Cells. 2020;9:1823.

4. Ueda S, Chen-Yoshikawa TF, Tanaka S, Yamada Y, Nakajima D, Ohsumi A, et al Protective effect of necrosulfonamide on rat pulmonary ischemia-reperfusion injury via inhibition of necroptosis. J Thorac Cardiovasc Surg. 2022;163: e113-22.

5. Gennai S, Monsel A, Hao Q, Park J, Matthay MA, Lee JW. Microvesicles derived from human mesenchymal stem cells restore alveolar fluid clearance in human lungs rejected for transplantation. Am J Transplant. 2015;15:2404-12.

6. Laing RW, Stubblefield S, Wallace L, Roobrouck VD, Bhogal RH, Schlegel A, et al The delivery of multipotent adult progenitor cells to extended criteria human donor livers using normothermic machine perfusion. Front Immunol. 2020;11:1226. 